\title{
Organizational Culture and Employee Empowerment at National Strategic Manufacturing Companies
}

\author{
Djoko Pitoyo \\ Universitas Sangga Buana, Bandung, Indonesia. \\ Email : djoko_pitoyo13@yahoo.com
}

\begin{abstract}
The national strategic manufacturing companies have a great contribution to GDP. However, these developments and growth are very volatile towards a drastic decline in 2016. The purpose of this study is to know and analyze the influence of leadership, organizational culture, and job characteristics on employee empowerment at the National Strategic Manufacturing Companies in West Java. This research was conducted by using survey method with quantitative approach. The research was conducted on five national strategic manufacturing companies located in West Java, Indonesia, with a population of 879 leaders equivalent to lower managers and a sample of 274 leaders. Data were obtained from survey through questionnaires distributed to the leaders. Data were processed using descriptive statistical analysis and SEM analysis. The results show that organizational culture, leadership, and job characteristics have positive and significant influence on employee empowerment.
\end{abstract}

Keywords: Organizational Culture; Leadership; Job Characteristics; Employee Empowerment; National Strategic Manufacturing Companies

\section{INTRODUCTION}

The growth of a country is determined by the development of its industries. One indicator of the progress of a nation can be seen from the growth of these industries, including industries in the manufacturing sector as the nation's economic support. The manufacturing companies is an economic activity which in the process of converting raw materials mechanically, chemically or by hand into semi-finished goods or finished goods and or from less valuable goods into highvalue goods, and closer to end-users [1]. In the era of globalization, Indonesia's manufacturing companies is expected to synergize in the face of companies and trade competition, both locally, regionally and internationally. The manufacturing companies has a large share of the country's foreign exchange earnings. In the international trade arena, the manufacturing companies has contributed $56 \%$ of the total national exports [2]. the value of Indonesian manufactured products exported in May 2017 worth US\$10.75 billion. Manufacturing outputs account for $75.25 \%$ of 
total exports or reach US\$14.29 billion, which means that Indonesia's exports are dominated by manufacturing outputs. Industrial Growth Ranking for G20 countries in 2016 and 2017 shows the poor ranking of Indonesia"s industrial economic growth among the countries. The efforts to increase the export of this manufacturing companies should be of serious concern to the Indonesian government. The government and exporters of the manufacturing companies must cooperate in a strategic breakthrough to increase the volume of non-oil and gas exports, in particular exports of manufactured products.

The government needs to encourage the growth of the manufacturing companies, especially in the state-owned enterprises (SOEs), by way of technology transfer, the introduction of new and more effective and efficient production methods through empowerment and improvement or development of human resources competencies both in management and employees and can create a work climate or culture that can making workers comfortable working. Employee empowerment is one of the effective techniques for improving productivity or performance for the employees themselves and optimizing the capacity of individual and group capabilities for organizational success goals. In other words, empowerment is a development strategy and organizational prosperity. Employee empowerment is giving employees the authority to plan, control, and make decisions about the work they are responsible for, without having to be explicitly authorized by the managers on it. If in empowerment, power is given by top management to lower managers (not to employees), in empowering employees instead the power is dug from within each employee through the process of empowerment. The granting of authority by management to employees is based on employee empowerment resulting from the empowerment process implemented by management of employees. Based on the phenomena occurring in each manufacturing companies mentioned above, it appears that there is a gap between the achievements of performance in the national strategic manufacturing companies with the target. This condition becomes a problem for the manufacturing companies, especially related to the management of employees as Human Resources (HR), low ability to manage human resources to produce superior performance in the manufacturing companies.

Thus, the purpose of this study is to: (1) describe the organizational culture, leadership, job characteristics, and employee empowerment at five National Strategic Manufacturing Companies in West Java; and (2) analyze the effect of organizational culture, leadership, and job characteristics on employee empowerment at five National Strategic Manufacturing Companies in West Java.

\section{METHOD}

This study is a quantitative approach by utilizing questionnaires as the main instrument of data collection. The data were analyzed by deceptive analysis to describe various characteristics of the variables studied. The verification analysis for hypothesis testing of this research was Structural Equation Modeling (SEM). This research was conducted at five national strategic manufacturing companies located in West Java. The population in this research is all 873 leaders or lower managers at the companies, with the sample of 274 leaders. In the model, The organizational culture is the latent exogenous variable that has seven manifest variables: attention to detail, outcome orientation, team orientation, aggressiveness, stability, innovation and risk taking, and people orientation. Leadership is the latent exogenous variable that has seven manifest variables: System Thinkers, Change Agents, Creators, Servants and Managers, Polycronic Coordinators, Instructors and Trainers, and Builders of Vision. The latent exogenous variable of job characteristics has six manifest variables: skill variety, tasks identity, tasks 
significance, autonomy, feedback from job, and feedback from others. Meanwhile, employee empowerment is the latent endogenous variable that has six manifest variables: Enabling, Facilitating, Consulting, Collaborating, Mentoring, and Supporting.

\section{RESULT AND DISCUSSION}

The descriptive analysis describes the average performance of each manifest variable, showing that all manifest variables are categorized as moderately high (range $=3.000-4.000$ from lowest $=1.000$ and highest $=5.000$ ). In organizational culture, attention to detail, innovation and risk taking, and people orientation are considered lower than outcome orientation, team orientation, aggressiveness, and stability. In leadership, the Creators, Instructors and Trainers, and Builders of Vision are relatively lower than System Thinkers, Change Agents, Servants and Managers, and Polycronic Coordinators.

In job characteristics, tasks identity, autonomy, and feedback from job are lower than skill variety, tasks significance, and feedback from others. In employee empowerment, Facilitating, Consulting, and Mentoring are relatively lower than Enabling, Collaborating, and Supporting.

The hypothesis testing using SEM consists of two steps. The first step is evaluation of outer model or measurement model, which includes the value of outer loading (valid when outer loading $>0.5$ and ideally outer loading $>0.7$ ). The second step is the evaluation of inner model (structural model), which includes the value of latent variable correlations, path coefficients, and $\mathrm{R}$-square $\left(\mathrm{R}^{2}\right)$, in terms of the variance of endogenous constructs explained by exogenous constructs. These outer loadings represent the absolute contribution of each manifest variable (dimension or indicator) in reflecting its latent variables. The results show that all manifest variables have a path loading/coefficient $>0.50$ that indicates that each manifest variable is significantly capable of reflecting each latent variable at five national strategic manufacturing companies in West Java. Structural equation in this model is formulated as follows:

Table 1. Structural Model

\begin{tabular}{|c|c|c|c|c|c|}
\hline & Model & Estimate & p-value & Significance & $\mathrm{RSq}$ and $\mathrm{e}$ \\
\hline \multirow[t]{3}{*}{ X4 } & $\mathrm{X} 1 \rightarrow \mathrm{X} 4$ & 0,352 & 0,000 & Significant & \multirow{3}{*}{$\begin{array}{c}\mathrm{RSq}=0,864 \\
\mathrm{e}=0,136\end{array}$} \\
\hline & $\mathrm{X} 2 \rightarrow \mathrm{X} 4$ & 0,286 & 0,000 & Significant & \\
\hline & $\mathrm{X} 3 \rightarrow \mathrm{X} 4$ & 0,363 & 0,000 & Significant & \\
\hline
\end{tabular}

$$
\begin{array}{r}
\mathrm{Y}=0.352 \mathrm{X} 1+0.286 \mathrm{X} 2+0.363 \mathrm{X} 3, \ldots \\
\text { with } \mathrm{R}^{2}=0.864 \text { and } \varepsilon=0.136
\end{array}
$$

$\mathrm{R}$-square value of 0.864 indicates a significant influence of organizational culture (X1) leadership (X2), and job characteristics (X3) on employee empowerment (Y), meaning that $86.4 \%$ variance of employee empowerment can be explained by organizational culture, leadership, and job characteristics, and $13.6 \%$ is influenced by other factors not examined in this model. The value also indicates the importance of organizational culture, leadership, and job characteristics to improve the employee empowerment at five national strategic manufacturing companies in West Java.

This finding confirms the results of research related to the influence of these three variables on employee empowerment, that various actions related to operational and structural aspects need to be managed by the right leadership, and that the right organizational culture and innovative job characteristics in the internal environment the organization needs to be done as 
a beginning to capture new opportunities as a way to lead to employee empowerment [3]. The results of this study support the findings of this study which have implications for the proposition that leadership, organizational culture, and job characteristics in the National Strategic Manufacturing Industry in West Java can continue to be maintained and improved so that the impact is large on employee empowerment.

The influence of organizational culture partially on employee empowerment in the National Strategic Manufacturing Industry in West Java is also supported by the results of research from [4]-[6] Moon (2000), which essentially shows the influence of organizational culture on employee empowerment. Thus, the results of the study support the findings of this study which have implications for the proposition of this study that the organizational culture in the National Strategic Manufacturing Industry in West Java needs to be maintained and improved so that the impact can be greater on the achievement of employee empowerment.

The influence of leadership partially on employee empowerment in the National Strategic Manufacturing Industry in West Java is also supported by the results of research from [7]-[9], which essentially shows the influence of leadership on employee empowerment. Thus, the results of these studies support the findings of this study which have implications for the proposition of this study that leadership in the National Strategic Manufacturing Industry in West Java needs to be maintained and improved so that the impact can be greater on employee empowerment.

The influence of job characteristics partially on employee empowerment in the National Strategic Manufacturing Industry in West Java is also supported by the results of research from [3], [10], [11],which essentially show the influence of Job characteristics towards employee empowerment. Thus, the results of these studies support the findings of this study which have implications for the research proposition that job characteristics in the National Strategic Manufacturing Industry in West Java need to be optimized so that the impact can be greater on employee empowerment.

\section{CONCLUSION}

Based on the research, it can be concluded that the contribution of organizational culture and job characteristics to employee empowerment is relatively large, while the leadership contribution to employee empowerment in the National Strategic Manufacturing Industry in West Java tends to be not so large. Referring to the results of the calculation that the influence of leadership on employee empowerment is still relatively high compared to the influence of organizational culture and job characteristics, the first step that needs to be considered by the company to improve employee empowerment is to focus on aspects of leadership that are in line with the employee empowerment program in the National Strategic Manufacturing Industry in West Java. The next step that can be taken is to continue to maintain high achievement and large contributions, namely the influence of organizational culture and job characteristics on employee empowerment.

\section{REFERENCES}

[1] K. Hitomi, "Manufacturing Systems Engineering.” Routledge, 2017.

[2] "Performance Accountability Report of Government Agencies Ministry of SOEs," Washington, 2017. 
[3] I. O. Ugboro and K. Obeng, "Top management leadership, employee empowerment, job satisfaction, and customer satisfaction in TQM organizations: an empirical study," J. Qual. Manag., vol. 5, no. 2, pp. 247-272, 2000.

[4] D. L. Goetsch and S. B. Davis, Quality management for organizational excellence. Upper Saddle River, NJ: pearson., 2014.

[5] N. D. Çakar and A. Ertürk, "Comparing Innovation Capability of Small and MediumSized Enterprises: Examining the Effects of Organizational Culture and Empowerment,” J. Small Bus. Manag., vol. 48, no. 3, pp. 325-359, 2010.

[6] M. J. Moon, “Organizational Commitment Revisited in New Public Management: Motivation, Organizational Culture, Sector, and Managerial Level," Public Perform. Manag. Rev., vol. 24, no. 2, p. 177, 2000.

[7] X. Zhang and K. M. Bartol, "Linking Empowering Leadership and Employee Creativity: The Influence of Psychological Empowerment, Intrinsic Motivation, and Creative Process Engagement," Acad. Manag. J., vol. 53, no. 1, pp. 107-128, 2010.

[8] C. A. Martin, "Psychological Climate, Empowerment, Leadership Style, and CustomerOriented Selling: An Analysis of the Sales Manager-Salesperson Dyad," J. Acad. Mark. Sci., vol. 34, no. 3, pp. 419-438, 2006.

[9] W. Zhu, D. R. May, and B. J. Avolio, "The Impact of Ethical Leadership Behavior on Employee Outcomes: The Roles of Psychological Empowerment and Authenticity," J. Leadersh. Organ. Stud., vol. 11, no. 1, pp. 16-26, 2004.

[10] M. Manojlovich and H. K. Spence Laschinger, "The Relationship of Empowerment and Selected Personality Characteristics to Nursing Job Satisfaction," JONA J. Nurs. Adm., vol. 32, no. 11, pp. 586-595, 2002.

[11] M. Lee and J. Koh, "Is empowerment really a new concept?," Int. J. Hum. Resour. Manag., vol. 12, no. 4, pp. 684-695, 2001. 